\title{
An update on the detection methods of Parachlamydia acanthamoebae, an atypical agent of pneumonia
}

\author{
Avinash Rames* \\ Division of Biomedical Sciences and Biotechnology, School of Health Sciences, International Medical University, 126, Jln Jalil Perkasa 19, Bukit \\ Jalil, 57000, Kuala Lumpur, Malaysia
}

Received 23rd May 2019 / Accepted 8th July 2019

\begin{abstract}
Parachlamydia acanthamoebae ( $P$. acanthamoebae) has been recognized as an emerging agent of pneumonia as it has been identified in human samples via culture-based, molecular and serological techniques. Additionally, studies on animal models have shown that it fulfills the third and fourth Koch postulates to be assigned a pathogenic role. Due to the threat posed by it, multiple tools have been employed in the search for $P$. acanthamoebae. The methods utilized for its detection would be cell culture based approaches which involve both animal and amoebal cell culture and also molecular techniques that encompasses polymerase chain reaction (PCR), fluorescence in situ hybridization (FISH) and in situ hybridization (ISH). Additionally, immunohistochemistry (IHC) and serology based techniques such as direct and indirect immunofluorescence are also employed with the usage of Western blotting or immunoblotting as confirmatory procedures. This review attempts to describe the variety of techniques that are present in literature for the isolation and identification of $P$. acanthamoebae.
\end{abstract}

Keywords: Atypical agent, culture-based, detection, molecular techniques, pneumonia, serology

\section{INTRODUCTION}

The origins of the word pneumonia can be traced back to the ancient Greek where the word "pneumon" means "lung" and therefore the word pneumonia means "lung disease" (Sattar and Sharma, 2018). Pneumonia is defined as an infection of one or both sides of the lungs which leads to the alveoli of the lungs to be filled with pus (Pneumonia | National Heart, Lung, and Blood Institute (NHLBI), 2018). The morbidity and mortality contributed by the condition is high as it kills about 2,400 children a day aged under five, with a total death toll of about 880,000 children in 2016 (Pneumonia in Children Under Five- UNICEF DATA, 2018). A search of literature would reveal that there are multiple etiologic agents commonly ascribed to be causes of the condition (Figure 1). Due to the ubiquity of these agents and the fact that a large portion of cases cannot have an etiology pinpointed, it is common to overlook organisms which are not traditionally noted for causing pneumonia. Parachlamydia acanthamoebae ( $P$. acanthamoebae) is one such example. $P$. acanthamoebae is a Chlamydialike organism which is obligately intracellular that has been noted to infect free-living Acanthamoeba (Hayashi et al., 2010). It can stain either Gram positive or Gram negative depending on its infectious stage (Amann et al., 1997). The life cycle of $P$. acanthamoebae in Acanthamoeba polyphaga ( $A$. polyphaga) is well documented and it has been demonstrated that there are three varying development stages for the said pathogen which

*Author for correspondence: Avinash Rames, Division of Biomedical Sciences and Biotechnology, School of Health Sciences, International Medical University, 126, Jln Jalil Perkasa 19, Bukit Jalil, 57000, Kuala Lumpur, Malaysia. Email - avinashrames@gmail.com 
would be the reticulate, elementary and crescent bodies (Amann et al., 1997; Greub and Raoult, 2002a). The various developmental stages of $P$. acanthamoebae have been identified to be distributed in varying compartments of the amoebal cell yet all of them have a similarity whereby they are commonly visualized in the vacuoles of the amoeba (Greub and Raoult, 2002a). However, reticulate bodies are predominantly found in the cytoplasm of the host while the crescent bodies appear to be occasionally present in close proximity of the host. The infective stages of $P$. acanthamoebae have been identified to be the elementary and crescent bodies and their intake is mediated by phagocytic action of the amoebal host cell (Greub and Raoult, 2002a). Due to the ubiquity of amoeba in the environment, it can be postulated that they may act as a reservoir or a vector of sorts for $P$. acanthamoebae. Indeed, $P$. acanthamoebae has been identified in Acanthamoeba mauritaniensis (A. mauritaniensis) and Acanthamoeba castellani ( $A$. castellani) which were isolated from the nasal mucosa of healthy volunteers (Amann et al., 1997). Additionally, the presence of $P$. acanthamoebae has been noted in bovines, ruminants, reptiles, boars and even guinea pigs (Borel et al., 2007; Di Francesco et al., 2013; Lutz-Wohlgroth et al., 2006; Ruhl et al., 2008; Soldati et al., 2004). As such, it is possible that these animals could be efficient vectors or reservoirs as some of them are kept as pets by people while the remaining fall under the livestock category.

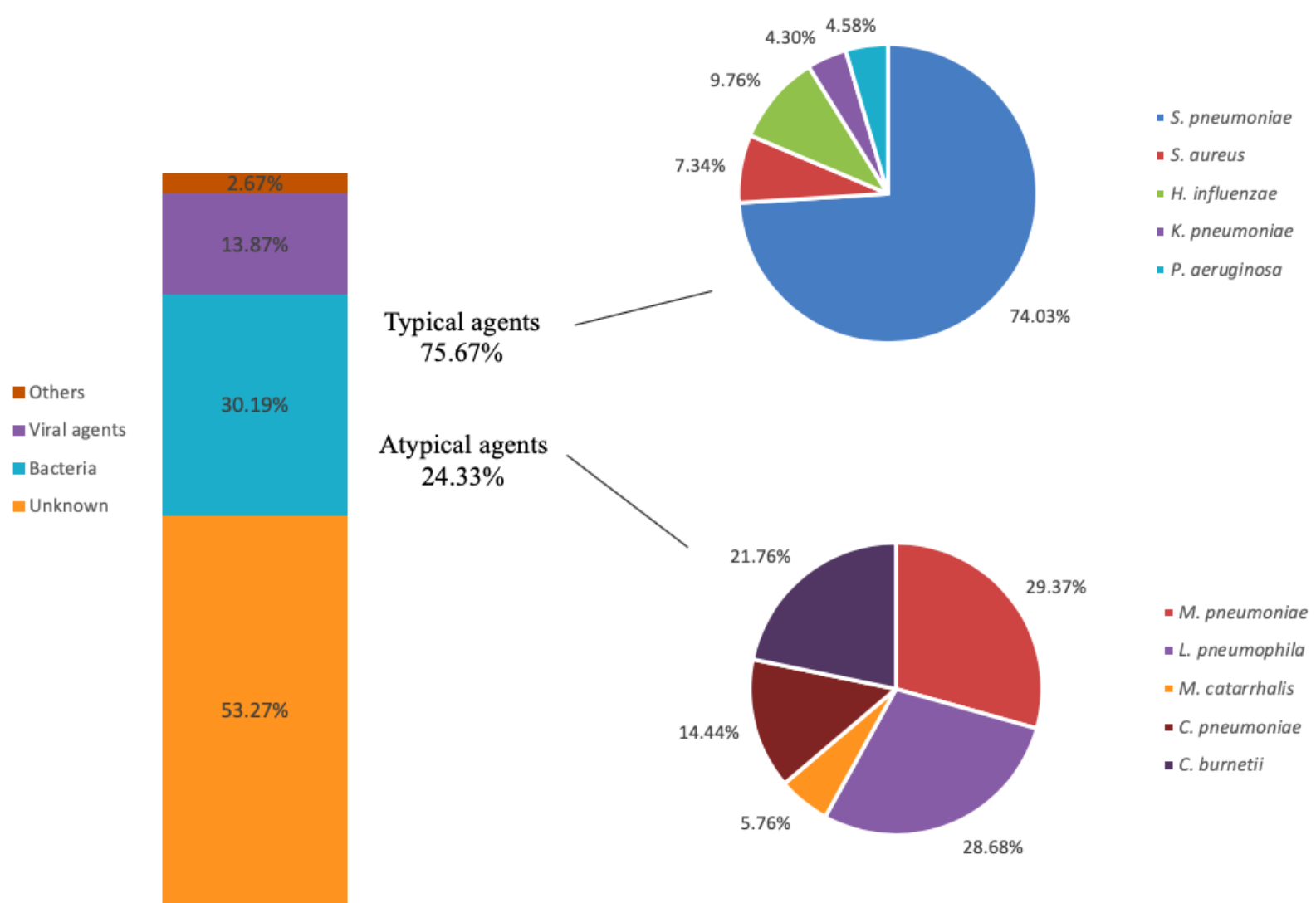

Figure 1. Distribution of various etiologic agents of CAP $(\mathrm{N}=13673)$ on the basis of review of literature, 2009-2019. Abbreviated pathogens are Streptococcus pneumoniae, Staphylococcus aureus, Haemophilus influenzae, Klebsiella pneumoniae, Pseudomonas aeruginosa, Mycoplasma pneumoniae, Legionella pneumophila, Moraxella catarrbalis, Chlamydia pneumoniae and Coxiella burnetii. (Akter et al., 2014; Aliberti et al., 2013; Caggiano et al., 2017; Capelastegui et al., 2012; Cillóniz et al., 2011; Farida et al., 2015; Holter et al., 2015; Huijskens et al., 2013; Jain et al., 2015; Köksal et al., 2010; Luchsinger et al., 2013; Lupisan et al., 2019; Mermond et al., 2010; Naik et al., 2010; Nascimento-Carvalho et al., 2016; Quah et al., 2018; Shibli et al., 2010; Spoorenberg et al., 2014; van Gageldonk-Lafeber et al., 2013). 
Previous research is strongly suggestive of the notion that $P$. acanthamoebae is an emerging pathogen. The first instance of this would be the identification of Hall's coccus in an amoeba which was isolated from a case of humidifier-associated fever (Birtles et al., 1997). A study done on community-acquired pneumonia (CAP) patients in Nova Scotia, Canada, revealed a seroconversion rate of $2.2 \%$ towards $P$. acanthamoebae whereby 8 out of 371 patients had antibodies which were directed against it compared to 0 out of 511 healthy volunteers (Marrie et al., 2001). The data garnered suggests that it is not a normal component of the human microbiome, however literature search purports that it is likely an opportunistic pathogen of the respiratory system. Indeed, $P$. acanthamoebae was detected in an individual that was under immunosuppressants after receiving an allograft (Marrie et al., 2001). Additionally, it was also identified in a human immunodeficiency virus (HIV)-positive patient that only had 80 CD4 cells $/ \mathrm{mm}^{3}$ (Greub, Berger, et al., 2003). The stance is supported further by a study from Greub and coworkers which identified notable antibody titers against $P$. acanthamoebae in 5 out of 37 $(13.5 \%)$ polytraumatized intensive care unit patients (Greub, Boyadjiev, et al., 2003). Its medical burden has also been noted in children, which are a population group that do not have completely developed immune systems (Lamoth et al., 2011). The success of $P$. acanthamoebae as an opportunistic respiratory pathogen may lie in its temperature dependent lytic activity. The pathogen has been noted to cause the lysis of $A$. polyphaga at temperatures between $32-37^{\circ} \mathrm{C}$ while remaining an endosymbiont at $25-30^{\circ} \mathrm{C}$ (Greub, La Scola, et al., 2003). Therefore, it is proposed that the bacteria employ amoeba as a reservoir while in the surrounding environment and is liberated via lysis of the amoeba once it is at a higher temperature such as that in the respiratory tract. The concern raised by the pathogen is worrisome as it has been detected via molecular methods in the hospital environment itself (Fukumoto et al., 2010).

The isolation of $P$. acanthamoebae is a laborious process as the pathogen is obligately intracellular and therefore the conventional "gold standard" culture methods will not yield results. The fastidious intracellular pathogen is only cultivatable from clinical samples via the usage of amoebal co-culture techniques which are not routinely performed in diagnostic laboratories (Greub, 2009). Adding to the conundrum, would be the absence of specific tests or diagnostic kits to identify its presence in a sample. The amount of detection techniques present for it are chiefly molecular based methods and these are also not commonly done for $P$. acanthamoebae. Due to the delay in identifying the pathogen, the administration of treatment is also impeded hence contributing to further decline in the patient's health. Within this context, this review attempts to describe the variety of techniques that are present in literature for the isolation and identification of $P$. acanthamoebae.

\section{Culture based methods}

The utilization of culture based techniques for the purpose of identification is rather time consuming, yet it has the benefit of permitting the recovery of actual strains of the pathogen hence adding to the knowledge pool available pertaining it. Additionally, it removes the element of doubt from a diagnosis whereby the existence of viable organisms can be illustrated by the propagation of the said organism in vitro. A search of literature would reveal that in the context of $P$. acanthamoebae, there are two different types of culture based methods for pathogen identification.

\subsection{Amoebal co-culture}

This system can be described as a variant of conventional cell culture whereby instead of normal cells, amoeba are employed as the cells (Greub, 2009). The common amoeba used in this strategy are Acanthamoeba spp., as they have been demonstrated to be the natural hosts for multiple amoeba-resisting bacteria (Corsaro and Greub, 2006). In utilizing Acanthamoeba spp., for the isolation of $P$. acanthamoebae, A. castellani appears to be the most commonly employed species yet it should be noted that there is a paucity of literature which recommends the usage of a specific species. As such, it is suggested that multiple species of Acanthamoeba and/or different genus of amoeba should be considered as it may enhance recovery rates of $P$. acanthamoebae. The amoebal co-culture 
strategy can be divided into two different types which would be the direct amoebal co-culture and the amoebal enrichment method. In direct amoebal co-culture, amoebae are used as the cell background and clinical samples are added in to isolate out the $P$. acanthamoebae that may be present in the sample (Greub and Raoult, 2002b). In amoebal enrichment, the goal is to recover amoebae that are free-living. This is done via addition of the clinical sample to non-nutrient agar which is supplemented with either living Escherichia coli (E. coli) or Enterobacter cloacae, followed by an incubation at $25-30^{\circ} \mathrm{C}$ and daily observation for amoebal presence which should then be examined for the presence of $P$. acanthamoebae (Greub and Raoult, 2002b). In a clinical setting the former could be possibly more effective as it may allow the direct isolation of $P$. acanthamoebae from samples while the latter could have higher efficacy in infections which are polymicrobial in nature as it will allow the amoebae to be isolated out hence permitting the recovery of $P$. acanthamoebae.

\subsection{Cell culture}

Prior research suggests that cell cultures are generally unsuccessful in recovering $P$. acanthamoebae from samples. A study by Hayashi and colleagues revealed that no growth of the pathogen was observed in HEp-2, Vero, Jurkat and THP-1 cells (Hayashi et al., 2010). It can be postulated that the absence of growth was due to a loss of receptors or intake systems in mammalian cells which have adapted to stable culture environments. The finding by Hayashi et al., is contradicted by Yamane and coworkers as they discovered that growth in Hep-2 cells is indeed possible at temperatures lower than the normal human body temperature albeit exhibiting low infectious rates (Yamane et al., 2015). Adding to the conundrum, data from another group identified that $P$. acanthamoebae is able to enter and multiply within human macrophages in addition to causing apoptosis in the immune cells (Greub, Mege, et al., 2003). This could probably be a survival mechanism of the pathogen whereby macrophages are utilized as a temporary replicative niche prior attachment to cells that are more suited for its growth. Indeed, it has been illustrated that $P$. acanthamoebae has the capability to enter and multiply within pneumocytes and fibroblasts yet the viability of these cells is not compromised post-infection (Casson et al., 2006). This data is suggestive that these cells may just be a temporary intrapulmonary niche for the strictly intracellular pathogen prior to exhibiting virulence or infecting better targets. It is rather vivid that the efficacy of mammalian cell culture for isolating $P$. acanthamoebae is questionable and as such alternatives should be explored.

Interestingly, the academic community has also conducted research on the use of cell lines from fish and insects for permissivity towards $P$. acanthamoebae. Work done on cell lines from Aedes albopictus (Asian tiger mosquito), Spodoptera frugiperda (fall armyworm) and Drosophila melanogaster (common fruit fly) demonstrated that $P$. acanthamoebae is able to replicate in the said cells albeit inducing severe cytotoxic effects in them (Sixt et al., 2012). This stance is challenged by another group which highlights that $P$. acanthamoebae is not able to grow in cells from the Asian tiger mosquito and fall armyworm (KebbiBeghdadi et al., 2015). It is possible that the cells may have just taken varying times to adapt to the varying culture conditions hence causing the discrepancy. In the context of fish cell lines, the permissivity of cells from Pimephales promelas (fathead minnow) and Oncorbynchus mykiss (rainbow trout) towards P. acanthamoebae has been identified to be unsatisfactory (Kebbi-Beghdadi et al., 2011). The data obtained is suggestive that fish and insects are either niches for differentiation or a reservoir before infecting organisms that are better suited. Nevertheless, more work should be done on insect cell lines as it has the potential to be a new arsenal in the tools available for the diagnosis of $P$. acanthamoebae. However, the feasibility is questionable as well, as having insect cell lines for the diagnosis of a single pathogen does not seem economically rewarding for diagnostic laboratories.

\section{Molecular Techniques}

Molecular methods are commonplace in clinical microbiology as they are utilized to detect and/or identify the presence of microbes in clinical samples (Corsaro and Greub, 2006). These techniques are rather rewarding in the clinical 
setting as they permit the diagnosis/detection of pathogens that may be fastidious.

\subsection{Polymerase chain reaction (PCR) method}

PCR is a process which consists of three sequential steps that are denaturation, annealing and extension (Ghannam and Varacallo, 2019). Denaturation occurs when the sample is heated up until about $95^{\circ} \mathrm{C}$ which causes disruption of the hydrogen bonds that hold the two strands of DNA template together. The sample then has its temperature reduced to about $50-65^{\circ} \mathrm{C}$ depending on the primer employed which then permits annealing of complementary base pairs. The final step, extension occurs at about $75-80^{\circ} \mathrm{C}$ which permits the DNA polymerase to synthesize new DNA strands that would be complementary to the template DNA strand.

The literature pertaining to the usage of PCR in the diagnosis of $P$. acanthamoebae suggests that the $16 \mathrm{~S}$ ribosomal RNA (rRNA) is a commonly targeted region for amplification. This is not a surprise as targeting this gene is phylogenetically informative and as such will permit the identification of new strains or species. Casson et al. (2008) report a real time-PCR that target the $16 \mathrm{~S}$ rDNA-encoding gene which exhibits high sensitivity and specificity. The sensitivity was just 10 copies of genomic $\mathrm{DNA} / \mu \mathrm{L}$ while the specificity was illustrated via testing with genomic DNA of humans, fungi and bacteria which all yielded negative results (Casson, Posfay-Barbe, et al., 2008). Similar PCR based methods targeting the 16S rDNA for amplification are reported elsewhere (Amann et al., 1997; Fukumoto et al., 2010; Le Faou et al., 2001). Despite the aforementioned efficacy in the usage of $16 \mathrm{~S}$ rDNA as a target for PCR amplification, there are some issues surrounding its employment. Indeed, multiple authors have managed to amplify samples of pathogens that have been isolated (Le Faou et al., 2001; Wheelhouse et al., 2010, 2011). However, subsequent analysis via bioinformatics commonly revealed that the pathogens are only from a certain genus or that the organisms identified have a certain percentage of sequence similarity to an existing pathogen (Wheelhouse et al., 2010, 2011). As such, the discriminatory power and specificity can be questionable at times. Consequently, a positive PCR result obtained via the use of these primers may not necessarily mean that $P$. acanthamoebae has been detected but rather it could indicate the identification of a new species or strain. On a positive light, it does add to the pool of knowledge present pertaining a pathogen yet it may not hold much value in a clinical setting.

There is a paucity of literature pertaining the use of genes other than the 16S rRNA. A study by Soldati and collaborators describes the use of $23 \mathrm{~S}$ rDNA which was Chlamydiales order-specific to detect P. acanthamoebae (Soldati et al., 2004). The study revealed that the sensitivity was better than culture based techniques employed. However, the length of the fragment generated via the PCR was rather limited and hence did not permit the conduction of phylogenetic analysis and comparative analysis. Another gene of interest for PCR amplification to detect $P$. acanthamoebae is the tlc gene. It encodes the nonmitochondrial ADP/ATP translocase that is involved in the exchange of bacterial ADP for ATP from the host cell hence permitting energy parasitism (Greub and Raoult, 2003). Work by Greub and coworkers utilized this gene as a target for PCR on bronchoalveolar lavage samples and reported that it was indeed effective albeit having false-positives (Greub, Berger, et al., 2003). A theory proposed to explain the false negative would be the gene used for the amplification itself. Indeed, the tlc gene is present in Rickettsiales, Chlamydiales, plant and alga plastids hence it may lead to cross-amplification which would result in false-positives (Greub and Raoult, 2003). However the gene is still suigeneris in bacteria as the bacterial version of the tlc gene product is absent of a $\mathrm{N}$-terminal peptide transit of approximately 90 and 150 amino acids which is only present in green plants and alga plastids (Greub and Raoult, 2003). Due to this variance, it does add a certain amount of discriminatory power for the PCR assays which target this gene for the detection of $P$. acanthamoebae.

Collectively, existing literature demonstrates that previous authors have emphasized much on utilizing the 16S rRNA encoding gene as the PCR amplification target. The 23S rRNA encoding gene and tlc gene are merely being supplemental in nature when compared with the work done on the previous gene sequence. The data presented warrants that additional research should be conducted on optimizing the sequences employed during use of the $16 \mathrm{~S}$ rRNA encoding gene as 
there appears to be a certain lack of discriminatory power as reported by authors. The $16 \mathrm{~S}$ rRNA gene has been noted to be omnipresent in all prokaryotes and it contains both fast-evolving and slow-evolving regions (Sambo et al., 2018). As such, it is possible to design broad-spectrum primer pairs targeting the slow-evolving regions to obtain a PCR product and subsequently sequence information from the generated amplicon can be utilized to isolate out the speciesspecific fast-evolving regions hence contributing to an overall increase in discriminatory power (Sambo et al., 2018). The key challenge of using the $23 \mathrm{~S}$ rRNA encoding gene would be the dearth of established broad-range bacterial PCR amplification and sequencing primers and hence the solution would be to develop novel PCR assays targeting the said gene (Hunt et al., 2006). In line with this, effort should also be placed in the direction of identifying new gene sequences that would permit the development of superior PCR based assays for the detection of $P$. acanthamoebae. It is suggested that PCR assays which target the internal transcribed spacer (ITS) region that links the $16 \mathrm{~S}$ and $23 \mathrm{~S}$ regions should be developed. Indeed, this has been employed before to detect and discriminate between various organisms such as Lactococcus garvieae, Streptococcus iniae, Vibrio spp., Campylobacter spp., Legionella spp, and Clostridium difficile (Berridge et al., 1998; Hoffmann et al., 2010; Mendoza et al., 1998; Riffard et al., 1998; Stubbs et al., 1999; Thanh et al., 2013). Targeting the ITS region for PCR has the inherent advantage of permitting intraspecies differentiation as species-species sequence polymorphisms can be detected easily because the ITS region varies greatly in size and sequence among closely related bacterial species in comparison with the more evolutionarily constrained 16S and 23S rRNA genes (Berridge et al., 1998; Hoffmann et al., 2010; Riffard et al., 1998). Additionally, bacteria may have multiple alleles of the rRNA gene cluster and as such this would permit the differentiation of epidemiologically related and unrelated strains in addition to potentially increasing the sensitivity of the PCR assay (Kiss et al., 1977; Thanh et al., 2013). In the context of $P$. acanthamoebae, there is only one PCR assay available which targets the ITS region and even then the primers targeting the region were Chlamydiaceae order specific hence indicating that this avenue has not been widely explored yet (Lutz-Wohlgroth et al., 2006).

\subsection{Fluorescence in situ hybridization (FISH)}

The primary step in FISH would be to prepare probes which would be complementary to the gene sequence that one would be searching for (Ratan et al., 2017). Labeling of the DNA probe can be done either directly or indirectly. In the former, probes are directly labeled with nucleotides containing a fluorophore while in the latter, the modified nucleotides containing a hapten would be labeled. However, for indirect labeling an extra step would be required to permit visualization of non-fluorescent hapten and this requires either an enzymatic or immunological detection system (Ratan et al., 2017; Speicher and Carter, 2005). Post-labeling, both the labeled probe(s) and the target DNA are denaturated to yield single-stranded DNA and then these are both combined hence permitting the annealing of complementary DNA sequences.

The efficacy of this technique to detect and identify microbes without any form of cultivation has been noted previously (Fritsche et al., 1999; Horn et al., 1999). In a clinical setting, this translates into a reduction of time required for diagnosis hence allowing prompt treatment of the patient. Additionally, FISH is commonly employed to analyze microbial communities in the context of composition and structure (Juretschko et al., 1998; Snaidr et al., 1997). This would be of high value in a diagnostic setting, as it could aid to discriminate $P$. acanthamoebae specifically if the infection in a patient is polymcrobial in nature. There exists a considerable body of literature pertaining the use of FISH for the detection of $P$. acanthamoebae (Amann et al., 1997; Hayashi et al., 2010; Matsuo et al., 2008). However, all the reports illustrate usage of FISH for $P$. acanthamoebae detection in Acanthamoeba spp. with the exception being a study by Hayashi et al. (2010) which describes detection in mammalian cells as well. Interestingly, another group utilized the precursor to FISH which was in situ hybridization (ISH) to detect $P$. acanthamoebae (Amann et al., 1997). The labeling was done with tetramethylrhodamine and horseradish peroxidase which is different from the usage of fluorescent probes employed in FISH. Their 
study demonstrated a cross-reaction between two different strains of $P$. acanthamoebae and this suggests that FISH would be a technique which has very little use in the context of phylogenetics.

Existing literature purports that FISH is a valuable technique to detect $P$. acanthamoebae due to its rapidity and specificity. It has also been used to identify genotypic antibiotic resistance in Helicobacter pylori towards clarithromycin hence indicating that such an avenue could exist for $P$. acanthamoebae as well (Yilmaz and Demiray, 2007). In light of reported works pertaining use of FISH in detecting $P$. acanthamoebae, it can be deduced that there is not much effort in this direction. This is indeed surprising as FISH has the potential to be an imperative diagnostic tool of $P$. acanthamoebae granted its aforementioned advantages. It is also very cost-effective as it has been reported that the total cost for materials in a FISH reaction is less than 1 euro (Frickmann et al., 2017). Accordingly, it is suggested that commercialization of FISH for the detection of $P$. acanthamoebae should be considered as the key obstacle is a lack of the techniques' usage in diagnostic laboratories (Frickmann et al., 2017). However, this could be argued against as well because designing probes for the detection of a pathogen that is an atypical agent of pneumonia may not be economically profitable in the long run for diagnostic laboratories. Valorization is possible by introducing FISH assays which would be functioning to detect a panel of intracellular pathogens that are etiologic agents of pneumonia and within this panel FISH probes that test for the presence of $P$. acanthamoebae can be included as well.

\section{Immunohistochemistry}

IHC is a technique which is employed to detect specific antigens that may be present in a tissue section via the usage of antibodies where they are then visualized by using enzymes which would react with a specific substrate hence resulting in color change. In the context of clinical microbiology, IHC has the advantage of being usable in patients that are awaiting culture results, having low bacterial loads and partially treated (Kundu et al., 2014). Additionally, it adds discriminatory power as the presence of $P$. acanthamoebae inside infected tissue can be illustrated hence demonstrating its role as an emerging agent of pneumonia. Indeed, a previous study supports the notion that $P$. acanthamoebae is an emerging pathogen as it fulfilled the third and fourth Koch postulates (Casson et al., 2008). The current application of IHC in detecting $P$. acanthamoebae appears to be identifying the etiologic agent for bovine abortions (Blumer et al., 2011; Borel et al., 2007; Lohr et al., 2015; Ruhl et al., 2009; Wheelhouse et al., 2012). Despite the difference in the organism being evaluated, it is proposed that the methods' efficacy would be retained in human samples as well if the pathogen being detected is similar. The emphasis appears to be on employing mice to produce the required antibodies to detect $P$. acanthamoebae and there is no difference in the usage rates of polyclonal and monoclonal antibodies (Blumer et al., 2011; Borel et al., 2007; Casson et al., 2007).

A significant portion of studies done pertaining the use of IHC to detect $P$. acanthamoebae in samples has employed the antibody production protocols which have been developed by Casson and coworkers (Regenscheit et al., 2012; Ruhl et al., 2009; Wheelhouse et al., 2012). The antibody developed by Casson and collaborators is indeed effective when employed to differentiate between distantly related Chlamydia like organisms as little or no crossreactivity was observed (Casson et al., 2007). However, significant cross reactivity was illustrated when the antibodies were utilized to detect Protochlamydia amoebophila (P. amoebaphila) and $P$. acanthamoebae as the two species are rather closely related (Casson et al., 2007). This puts the specificity and sensitivity of the antibody itself under scrutiny as it may contribute to erroneous results in a clinical setting. In the light of this finding, it is possible that other works may have the issue as well as there is an absence of crossreactivity evaluation. The majority of prior work illustrates that IHC is indeed a valuable tool in the armamentarium against $P$. acanthamoebae hence explaining its widespread use. However, caution should be practiced in interpreting results from IHC due to the possibility of cross-reaction. It is proposed that the employment of this protocol should be followed up with additional testing via molecular techniques such as PCR or FISH. 
Table 1. Primers and probes for the detection of P. acanthamoebae present in literature.

\begin{tabular}{|c|c|c|c|}
\hline Technique & Target gene & Primers & Reference \\
\hline \multirow{6}{*}{ PCR } & \multirow{4}{*}{$\begin{array}{l}\text { 16S rRNA- } \\
\text { encoding } \\
\text { gene }\end{array}$} & $\begin{array}{c}\text { PacR, 5'-CTCAGCGTCAGGAATAAGC-3' } \\
\text { PacS, 5'-TTCCACATGTAGCGGTGAAATGCGTAGATAATG-3' }\end{array}$ & $\begin{array}{l}\text { (Casson, } \\
\text { Posfay- } \\
\text { Barbe, et al., } \\
\text { 2008) }\end{array}$ \\
\hline & & $\begin{array}{l}\text { PacI, 5' -GAGGTGAAGCAAATCCCAAA-3' } \\
\text { Pac2, 5' -CTCCT'TGCGGTTAAGTCAGC-3' }\end{array}$ & $\begin{array}{l}\text { (Fukumoto et } \\
\text { al., 2010) }\end{array}$ \\
\hline & & $\begin{array}{l}\text { FOR2, 5' -CGTGGATGAGGCATGCAAGTCGA-3' } \\
\text { REV2, 5' -CAATCTCTCAATCCGCCTAGACGTCTTAG-3' }\end{array}$ & $\begin{array}{l}\text { (Wheelhouse } \\
\text { et al., 2011) }\end{array}$ \\
\hline & & $\begin{array}{l}\text { 16SIGF, 5'-CGGCGTGGATGAGGCAT-3' } \\
\text { 16SIGR, 5'-TCAGTCCCAGTGT'TGGC-3' }\end{array}$ & $\begin{array}{l}\text { (Everett et al., } \\
1999)\end{array}$ \\
\hline & $\begin{array}{l}23 \mathrm{~S} \text { rRNA- } \\
\text { encoding } \\
\text { gene }\end{array}$ & $\begin{array}{l}\text { 23SAPF2, 5'-GAACCTGAAACCAAGTAGC-3' } \\
\text { 23SAPR, 5'-CTGGCTCATCATGCAAAAGG-3' }\end{array}$ & $\begin{array}{l}\text { (Soldati } e t \text { al., } \\
\text { 2004) }\end{array}$ \\
\hline & $\begin{array}{l}\text { ATP/ADP- } \\
\text { translocase- } \\
\text { encoding } \\
\text { gene (tlc) }\end{array}$ & $\begin{array}{c}\text { Adp81F, 5'-TAGTGATCTGCTACGGGATT'T-3' } \\
\text { Adp84R, 5'-TTGGATTAGGATATTGCAATT'T-3' } \\
\text { 6-FAM-5'-AACCT'TGTAGAAGTAACCTGGAAGAACCAGC-3'- } \\
\text { TAMRA }\end{array}$ & $\begin{array}{l}\text { (Greub, } \\
\text { Berger, et al., } \\
\text { 2003) }\end{array}$ \\
\hline \multirow{3}{*}{ FISH } & \multirow[t]{2}{*}{$\begin{array}{l}\text { 16S rRNA- } \\
\text { encoding } \\
\text { gene }\end{array}$} & Bn, 658,5 ' -TCCGTT'TTCTCCGCCTAC-3' & $\begin{array}{l}\text { (Hayashi } e t \\
\text { al., 2010; } \\
\text { Matsuo } \text { et al., } \\
\text { 2008; Sixt } e t \\
\text { al., 2012) }\end{array}$ \\
\hline & & UV7-763, 5'-TGCTCCCCCTTGCTTTCG-3' & $\begin{array}{c}\text { (Collingro et } \\
\text { al., 2005) }\end{array}$ \\
\hline & $\begin{array}{l}\text { 18S rRNA- } \\
\text { encoding } \\
\text { gene }\end{array}$ & EUK516, 5'-ACCAGACTTGCCCTCC-3' & $\begin{array}{l}\text { (Hayashi et } \\
\text { al., 2010; } \\
\text { Matsuo et al., } \\
\text { 2008; } \\
\text { Poppert et al., } \\
\text { 2002) }\end{array}$ \\
\hline ISH & $\begin{array}{l}\text { 16S rRNA- } \\
\text { encoding } \\
\text { gene }\end{array}$ & Bn, 658,5 ' -TCCGTT'TTCTCCGCCTAC-3' & $\begin{array}{c}\text { (Amann et al., } \\
\text { 1997) }\end{array}$ \\
\hline
\end{tabular}

6-FAM is 6-carboxyfluorescein, TAMR A is 6-carboxytetramethylrhodamine.

\section{Serology}

Serology can be defined as the study of proteins, chiefly antibodies present in blood and secretions such as saliva (Wine et al., 2015). It is minimally invasive and requires the immune system to operate effectively (Doneley and Health, 2006). Consequently, it only yields results when the presence of a pathogen is significant enough to contribute towards seroconversion (Doneley and Health, 2006). Additionally, serology permits the retrospective confirmation of an infection as it 
demonstrates differences between samples from the acute and convalescent phases effectively besides having the capability to identify chronic infections (Maggi et al., 2014; Nilsson et al., 2005). There appears to be an emphasis on employing immunofluorescence for the detection of $P$. acanthamoebae with direct and indirect immunofluorescence having rather similar usage rates (Greub, Boyadjiev, et al., 2003; Hayashi et al., 2012; Marrie et al., 2001; Pilloux et al., 2015). Similar to IHC, immunofluorescence allows visualization of $P$. acanthamoebae in cells or tissues which permits it to be ascribed as an etiological agent for the said disease. Despite the efficacy, care should be taken when interpreting positive results obtained via this technique as crossreactivity has been reported with $P$. amoebaphila (Casson et al., 2007). As has been previously reported in literature, it is recommended that procedures such as immunoblotting or Western blotting should be employed to ensure truly positive results (Casson et al., 2007; Greub et al., 2009; Greub, Boyadjiev, et al., 2003).

Enzyme-linked Immunosorbent Assay (ELISA) is widely employed as an analytical biochemistry assay. ELISA is rather favored among diagnostic laboratories due to its simplicity, specificity, sensitivity and high throughput nature (Sakamoto et al., 2018). In the context of $P$. acanthamoebae, the approach of employing ELISA for detection has not been well established. Indeed, the closest format of an ELISA identified in literature was that of a multiplexed serology approach which utilized fluorescent probes (Bousbia et al., 2013). Baud and collaborators compared five commercial ELISA kits and identified that one of it which employed 60-kDA chlamydial heat shock protein (cHSP60) as the antigen had cross reactivity with $P$. acanthamoebae (Baud et al., 2010). This suggests the presence of the said protein in P. acanthamoebae too albeit probably having different sequences and consequently this opens an avenue for the production of new recombinant antigens specifically for the detection of this intracellular pathogen. Greub et al. pioneered work pertaining ELISA for $P$. acanthamoebae when they pyrosequenced the genome of the bacteria and conducted 2D-gel electrophoresis to identify immunogenic proteins (Greub et al., 2009). They identified a total of 18 proteins in which parachlamydial protein $\mathrm{E}$ and $\mathrm{N}$ were recombinantly expressed in E. coli. The purified recombinant proteins were utilized in a direct ELISA assay and detection was possible with rabbit sera until a dilution value of $1 / 256$. Previous studies have shown that the proteins exhibiting highest antigenicity for $P$. acanthamoebae weigh approximately $48 \mathrm{kDa}, 60 \mathrm{kDa}$ and $70 \mathrm{kDa}$ (Casson et al., 2007; Corsaro and Greub, 2006). Information garnered from work by Greub and coworkers can be used to postulate that the proteins weighing $48 \mathrm{kDa}$ and $70 \mathrm{kDa}$ are elongation factor $\mathrm{Tu}$ and chaperonin GroEL respectively (Greub et al., 2009). These proteins have been previously described as being highly immunogenic in Chlamydia trachomatis ( $C$. trachomatis) (Sanchez-Campillo et al., 1999). Work done on the proteomic aspect of $P$. acanthamoebae infection also revealed elongation factor $\mathrm{Tu}$ and $\mathrm{Na}$ (+)-translocating NADH-ubiquinone oxidoreductase subunit $\mathrm{D}$ as immunogenic proteins (Leitsch et al., 2010). The former is well established as an immunogen while the latter has been identified as an indicator of bacterial virulence in Chlamydia pneumoniae (C. pneumoniae) and C. trachomatis (Häse et al., 2001).

Despite the efficacy of serological techniques in detecting pathogens, there are numerous pitfalls to techniques that fall under this group. The technique is merely a reflection of a patients' immune response and hence cannot provide an information on the microbial load or severity of infection (Fierz, 2004). It may also have questionable use in clinical settings as the immune response of an individual is commonly polyclonal in nature hence potentially rendering antigens present in a test panel ineffective (Fierz, 2004). However, as serology based diagnosis of $P$. acanthamoebae is already present, it is suggested that better suited antigen targets should be sought after to potentially improve the usage rates of these techniques in detecting P. acanthamoebae. 
Table 2. An overview of the advantages and limitations of various techniques employed in the isolation of $P$. acanthamoebae.

\begin{tabular}{|c|c|c|c|}
\hline Technique & Advantages & Limitations & References \\
\hline $\begin{array}{l}\text { Culture- } \\
\text { based } \\
\text { isolation }\end{array}$ & $\begin{array}{l}\text { - Permits recovery of actual strains of } \\
\text { the pathogen. } \\
\text { - Existence of viable organisms can } \\
\text { be illustrated. } \\
\text { - Population size can be inferred from } \\
\text { the sample. } \\
\text { - Influence of the pathogen on cells } \\
\text { can be assessed if cell culture is } \\
\text { utilized. } \\
\text { - High sensitivity if appropriate } \\
\text { isolation panel is used. }\end{array}$ & $\begin{array}{l}\text { - Technique and operator } \\
\text { sensitive. } \\
\text { - Risk of contamination leading to } \\
\text { erroneous results. } \\
\text { - Time consuming as there is an } \\
\text { incubation period prior to } \\
\text { illustration of the organisms' } \\
\text { presence. } \\
\text { Efficacy is limited in detecting } \\
\text { fastidious organisms. }\end{array}$ & $\begin{array}{l} \\
\text { (Figdor and } \\
\text { Gulabivala, 2008; } \\
\text { Kaur and Kaur, } \\
\text { 2015) }\end{array}$ \\
\hline PCR & $\begin{array}{l}\text { - Permits detection of pathogens that } \\
\text { - } \text { Aould be culture-negative. } \\
\text { - High intra-species discrimination. } \\
\text { - High specificity. } \\
\text { - Lower risk of contamination } \\
\text { - Usage of qPCR would permit } \\
\text { accurate quantification of microbial } \\
\text { load in samples. }\end{array}$ & $\begin{array}{l}\text { - Possibility of false negatives and } \\
\text { false positives. } \\
\text { - Unable to discriminate between } \\
\text { live and dead organisms. } \\
\text { - Prone to human error. }\end{array}$ & $\begin{array}{l}\text { (Berridge et al., } \\
\text { 1998; Hoffmann et } \\
\text { al., 2010; Kralik } \\
\text { and Ricchi, 2017; } \\
\text { Madico and Rice, } \\
\text { 2008; Maneg et al., } \\
\text { 2016; Morillo et } \\
\text { al., 2003; Navarro } \\
\text { et al., 2004; Riffard } \\
\text { et al., 1998; } \\
\text { Valasek and Repa, } \\
\text { 2005; Valones et } \\
\text { al., 2009) }\end{array}$ \\
\hline
\end{tabular}

- Possible to detect and identify pathogen in clinical samples without any form of cultivation.

- Permits identification of pathogen in clinical cases with polymicrobial infections.

- Technical requirement for the assay is low and hence permits usage in resource-limited areas.

FISH
- Can be developed to detect antimicrobial-drug resistance that are due to rRNA gene mutations.

- Useful in detecting fastidious organisms.

- Cost-effective in comparison with PCR.
- Requirement for an experienced and trained individual.

- Sensitivity is considerably below that of PCR in the analysis of primary materials.

- Increased difficulty in using it to pinpoint non-ribosomal antimicrobial-drug resistance mechanisms due to considerably lower concentration of such mRNAs in comparison with rRNAs.

(Frickmann et al., 2013, 2017;

Fritsche et al., 1999; Horn et al., 1999; Juretschko et al., 1998; Poppert et al., 2002; Snaidr et al., 1997; Yilmaz and Demiray, 2007) 


\begin{tabular}{|c|c|c|c|}
\hline IHC & $\begin{array}{l}\text { - The role of an organism in an illness } \\
\text { can be illustrated vividly. } \\
\text { - Can be used on patients awaiting } \\
\text { culture results. } \\
\text { - Possible to be used on samples with } \\
\text { low bacterial loads. } \\
\text { - Can be utilized on patients that have } \\
\text { already been partially treated. } \\
\text { - A permanent record of the sample } \\
\text { can be stored. }\end{array}$ & $\begin{array}{l}\text { - Possibility of cross-reaction. } \\
\text { Results can be ambiguous due to } \\
\text { nonspecific or weak staining. }\end{array}$ & $\begin{array}{c}\text { (Casson et al., } \\
\text { 2007; Ellis et al., } \\
\text { 2005; Guarner et } \\
\text { al., 2000; Kundu et } \\
\text { al., 2014) }\end{array}$ \\
\hline Serology & $\begin{array}{l}\text { - Minimally invasive. } \\
\text { - Possible to identify chronic } \\
\text { infections. } \\
\text { - Discriminates between samples } \\
\text { from acute and convalescent phases. } \\
\text { - The role of an organism in an illness } \\
\text { can be illustrated vividly when } \\
\text { immunofluorescence is used. } \\
\text { - Only yield response when a } \\
\text { pathogens presence is significant } \\
\text { enough to cause seroconversion } \\
\text { hence minimizing false positives. }\end{array}$ & $\begin{array}{l}\text { - Possibility of cross-reaction. } \\
\text { - Probability of false positives and } \\
\text { false negatives. } \\
\text { - The validity of a serology based } \\
\text { test can only be established for a } \\
\text { defined population. } \\
\text { - The antigen used as the target } \\
\text { highly affects the tests' } \\
\text { performance. }\end{array}$ & $\begin{array}{l}\text { (Doneley and } \\
\text { Health, 2006; } \\
\text { Fierz, 2004; Maggi } \\
\text { et al., 2014; } \\
\text { Nilsson et al., } \\
\text { 2005) }\end{array}$ \\
\hline
\end{tabular}

\section{CONCLUSION}

Over the years, the number of cases of CAP has experienced a rather significant increase and adding to the issue would be the various etiologic agents that cause the ailment. The present findings illustrate the multiple techniques present for the detection of $P$. acanthamoebae, in both human and animal samples. Succinctly, each method has its own sets of pros and cons. Therefore, it is proposed that detection procedures should be employed based on the clinical presentation of the patient and response to empirical therapy as the bacteria is an atypical agent of pneumonia. It is suggested that comparative analysis pertaining the efficacy of different detection techniques should be conducted to identify the situations in which they would be effective in. Additionally, further research should be done to develop novel detection techniques for the said pathogen as it would contribute towards improved detection of intracellular pathogens as a whole.

\section{REFERENCES}

Akter, S., Shamsuzzaman S. M., \& Jahan, F. 2014. Community acquired bacterial pneumonia: aetiology, laboratory detection and antibiotic susceptibility pattern. The Malaysian Journal of Pathology 36(2): 97-103.

Aliberti, S., Cilloniz, C., Chalmers, J. D., Zanaboni, A. M., Cosentini, R., Tarsia, P., Pesci, A., Blasi, F., \& Torres, A. 2013. Multidrug-resistant pathogens in hospitalised patients coming from the community with pneumonia: a European perspective. Thorax 68(11): 997-9.

Amann, R., Springer, N., Schönhuber, W., Ludwig, W., Schmid, E. N., Müller, K. D., \& Michel, R. 1997. Obligate Intracellular Bacterial Parasites of Acanthamoebae Related to Chlamydia spp. Applied and Environmental Microbiology 63(1): 115-21.

Baud, D., Regan, L., \& Greub, G. 2010. Comparison of five commercial serological tests for the detection of antiChlamydia trachomatis antibodies. European Journal of Clinical Microbiology \& Infectious Diseases 29(6): 669-675.

Berridge, B. R., Fuller, J. D., de Azavedo, J., Low, D. E., Bercovier, H., \& Frelier, P. F. 1998. Development of specific nested oligonucleotide PCR primers for the Streptococcus iniae 16S$23 \mathrm{~S}$ ribosomal DNA intergenic spacer. Journal of Clinical Microbiology 36(9): 2778-81.

Birtles, R. J., Rowbotham, T. J., Storey, C., \& Raoult, D. 1997. Chlamydia-like obligate parasite of free-living amoebae. The Lancet 349(9056). Elsevier: 925-6.

Blumer, S., Greub, G., Waldvogel, A., Hässig, M., Thoma, R., Tschuor, A., Pospischil, A., \& Borel, N. 2011. Waddlia, Parachlamydia and Chlamydiaceae in bovine abortion. Veterinary Microbiology 152(3-4): 385-393.

Borel, N., Ruhl, S., Casson, N., Kaiser, C., Pospischil, A., \& Greub, G., 2007. Paracblamydia spp. and related Chlamydia-like 
organisms and bovine abortion. Emerging Infectious Diseases 13(12):1904.

Bousbia, S., Papazian, L., Saux, P., Forel, J. M., Auffray, J. P., Martin, C., Raoult, D., \& La Scola, B., 2013. Serologic prevalence of amoeba-associated microorganisms in intensive care unit pneumonia patients. PLoS One 8(3): e58111.

Caggiano, S., Ullmann, N., De Vitis, E., Trivelli, M., Mariani, C., Podagrosi, M., Ursitti, F., Bertolaso, C., Putotto, C., Unolt, M., \& Pietravalle, A., 2017. Factors that negatively affect the prognosis of pediatric community-acquired pneumonia in district hospital in Tanzania. International Journal of Molecular Sciences 18(3): 623.

Capelastegui, A., España, P. P., Bilbao, A., Gamazo, J., Medel, F., Salgado, J., Gorostiaga, I., de Goicoechea, M. J. L., Gorordo, I., Esteban, C., \& Altube, L., 2012. Etiology of community-acquired pneumonia in a population-based study: link between etiology and patients characteristics, process-of-care, clinical evolution and outcomes. BMC Infectious Diseases 12(1):134.

Casson, N., Medico, N., Bille, J., \& Greub, G. 2006. Parachlamydia acanthamoebae enters and multiplies within pneumocytes and lung fibroblasts. Microbes and Infection 8(5): 1294-1300.

Casson, N., Entenza, J. M., \& Greub, G. 2007. Serological crossreactivity between different Chlamydia-like organisms. Journal of Clinical Microbiology 45(1): 234-236.

Casson, N., Entenza, J. M., Borel, N., Pospischil, A., \& Greub, G. 2008. Murine model of pneumonia caused by Parachlamydia acanthamoebae. Microbial Pathogenesis 45(2): 92-97.

Casson, N., Posfay-Barbe, K. M., Gervaix, A., \& Greub, G. 2008. New diagnostic real-time PCR for specific detection of Paracblamydia acanthamoebae DNA in clinical samples. Journal of Clinical Microbiology 46(4): 1491-1493.

Cillóniz, C., Ewig, S., Polverino, E., Marcos, M. A., Esquinas, C., Gabarrús, A., \& Torres, A. 2011. Microbial aetiology of community-acquired pneumonia and its relation to severity. Thorax 66(4): 340-346.

Collingro, A., Poppert, S., Heinz, E., Schmitz-Esser, S., Essig, A., Schweikert, M., \& Horn, M. 2005. Recovery of an environmental chlamydia strain from activated sludge by co-cultivation with Acanthamoeba sp. Microbiology 151(1): 301-309.

Corsaro, D. \& Greub, G. 2006. Pathogenic potential of novel Chlamydiae and diagnostic approaches to infections due to these obligate intracellular bacteria. Clinical Microbiology Reviews 19(2): 283-297.

Di Francesco, A., Baldelli, R., Donati, M., Cotti, C., Bassi, P., \& Delogu, M. 2013. Evidence for Chlamydiaceae and Parachlamydiaceae in a wild boar (Sus scrofa) population in Italy. Veterinaria Italiana 49(1): 119-122.

Doneley, B. 2006. Antibody serology: The good and the bad. In Proceedings of the North American Veterinary Conference (Vol. 20, pp. 1532-1536). The North American Veterinary Conference.

Ellis, A. E., Mead, D. G., Allison, A. B., Gibbs, S. E., Gottdenker, N. L., Stallknecht, D. E., \& Howerth, E. W. 2005. Comparison of immunohistochemistry and virus isolation for diagnosis of West Nile virus. Journal of Clinical Microbiology 43(6): 2904-2908.

Everett, K. D. E., Bush, R. M., \& Andersen, A. A. 1999. Emended description of the order Chlamydiales, proposal of Paracblamydiaceae fam. nov. and Simkaniaceae fam. nov., each containing one monotypic genus, revised taxonomy of the family Chlamydiaceae, including a new genus and five new species, and standards for the identification of organisms. International Journal of Systematic Bacteriology 49(2): 415-440.

Farida, H., Gasem, M. H., Suryanto, A., Keuter, M., Zulkarnain, N., Satoto, B., \& Severin, J. A. 2015. Viruses and Gram- negative bacilli dominate the etiology of communityacquired pneumonia in Indonesia, a cohort study. International Journal of Infectious Diseases 38: 101-107.

Fierz, W. 2004. Basic problems of serological laboratory diagnosis. Methods in Molecular Medicine 94: 393-427.

Figdor, D. \& Gulabivala, K. 2008. Survival against the odds: microbiology of root canals associated with post-treatment disease. Endodontic Topics 18(1): 62-77.

Frickmann, H., Hänle, A., Essig, A., Dekker, D., Boahen, K., Acquah, S., \& Marks, F. 2013. Fluorescence in situ hybridization (FISH) for rapid identification of Salmonella spp. from agar and blood culture broth-An option for the tropics? International Journal of Medical Microbiology 303(5): 277-284.

Frickmann, H., Zautner, A. E., Moter, A., Kikhney, J., Hagen, R. M., Stender, H., \& Poppert, S. 2017. Fluorescence in situ hybridization (FISH) in the microbiological diagnostic routine laboratory: a review. Critical Reviews in Microbiology 43(3). Taylor \& Francis: 263-293.

Fritsche, T. R., Horn, M., Seyedirashti, S., Gautom, R. K., Schleifer, K. H., \& Wagner, M. 1999. In situ detection of novel bacterial endosymbionts of Acanthamoeba spp. phylogenetically related to members of the order Rickettsiales. Applied and Environmental Microbiology 65(1): 20612.

Fukumoto, T., Matsuo, J., Hayashi, M., Oguri, S., Nakamura, S., Mizutani, Y., \& Matsuno, K. 2010. Impact of free-living amoebae on presence of Parachlamydia acanthamoebae in the hospital environment and its survival in vitro without requirement for amoebae. Journal of Clinical Microbiology 48(9): 3360-5.

Ghannam, M. G. \& Varacallo, M. 2019. Biochemistry, Polymerase Chain Reaction (PCR). StatPearls. StatPearls Publishing.

Greub, G. 2009. Parachlamydia acanthamoebae, an emerging agent of pneumonia. Clinical Microbiology and Infection 15(1): 18-28.

Greub, G. \& Raoult, D. 2002a. Crescent bodies of Parachlamydia acanthamoeba and its life cycle within Acanthamoeba polyphaga: an electron micrograph study. Applied and Environmental Microbiology 68(6): 3076-84.

Greub, G. \& Raoult, D. 2002b. Parachlamydiaceae: potential emerging pathogens. Emerging Infectious Diseases 8(6): 625-30.

Greub, G. \& Raoult, D. 2003. History of the ADP/ATPtranslocase-encoding gene, a parasitism gene transferred from a Chlamydiales ancestor to plants 1 billion years ago. Applied and Environmental Microbiology 69(9): 5530-5.

Greub, G., La Scola, B., \& Raoult, D. 2003. Paracblamydia acanthamoeba is endosymbiotic or lytic for Acanthamoeba polyphaga depending on the incubation temperature. Annals of the New York Academy of Sciences 990: 628-34.

Greub, G., Mege, J-L., \& Raoult, D. 2003. Parachlamydia acanthamoebae enters and multiplies within human macrophages and induces their apoptosis. Infection and Immunity 71(10): 5979-85.

Greub, G., Berger, P., Papazian, L., \& Raoult, D. 2003. Parachlamydiaceae as rare agents of pneumonia. Emerging Infectious Diseases 9(6): 755-6.

Greub, G., Boyadjiev, I., La Scola, B., Raoult, D., \& Martin, C. 2003. Serological hint suggesting that Parachlamydiaceae are agents of pneumonia in polytraumatized intensive care patients. Annals of the New York Academy of Sciences 990(1): 311-319.

Greub, G., Kebbi-Beghdadi, C., Bertelli, C., Collyn, F., Riederer, B. M., Yersin, C., \& Raoult, D. 2009. High throughput sequencing and proteomics to identify immunogenic proteins of a new pathogen: the dirty genome approach. Valdivia RH (ed.) PLoS One 4(12): e8423.

Guarner, J., Shieh, W. J., Dawson, J., Subbarao, K., Shaw, M., Ferebee, T., \& Zaki, S. R. 2000. Immunohistochemical and 
In Situ Hybridization Studies of Influenza A Virus Infection in Human Lungs. American Journal of Clinical Pathology 114(2): 227-233.

Häse, C. C., Fedorova, N. D., Galperin, M. Y., \& Dibrov, P. A. 2001. Sodium ion cycle in bacterial pathogens: evidence from cross-genome comparisons. Microbiology and Molecular Biology Reviews 65(3): 353-70.

Hayashi, Y., Nakamura, S., Matsuo, J., Fukumoto, T., Yoshida, M., Takahashi, K., ... \& Yamaguchi, H. .2010. Host range of obligate intracellular bacterium Parachlamydia acanthamoebae. Microbiology and Immunology 54(11): 707-713.

Hayashi, Y., Imin, Y., Matsuo, J., Nakamura, S., Kunichika, M., Yoshida, M., \& Yamaguchi, H. 2012. A domino-like chlamydial attachment process: concurrent Paracblamydia acanthamoebae attachment to amoebae is required for several amoebal released molecules and serine protease activity. Microbiology 158(6): 1607-1614.

Hoffmann, M., Brown, E. W., Feng, P. C., Keys, C. E., Fischer, M., \& Monday, S. R.2010. PCR-based method for targeting 16S-23S rRNA intergenic spacer regions among Vibrio species. BMC Microbiology 10(1): 90.

Holter, J. C., Müller, F., Bjørang, O., Samdal, H. H., Marthinsen, J. B., Jenum, P. A., \& Heggelund, L.2015. Etiology of community-acquired pneumonia and diagnostic yields of microbiological methods: a 3-year prospective study in Norway. BMC Infectious Diseases 15(1): 64.

Horn, M., Fritsche, T. R., Gautom, R. K., Schleifer, K. H., \& Wagner, M. 1999. Novel bacterial endosymbionts of Acanthamoeba spp. related to the Paramecium caudatum symbiont Caedibacter caryophilus. Environmental Microbiology 1(4): 357-67.

Huijskens, E. G., van Erkel, A. J., Palmen, F. M., Buiting, A. G., Kluytmans, J. A., \& Rossen, J. W. 2013. Viral and bacterial aetiology of community-acquired pneumonia in adults. Influenza and Other Respiratory Viruses 7(4): 567-73.

Hunt, D. E., Klepac-Ceraj, V., Acinas, S. G., Gautier, C., Bertilsson, S., \& Polz, M. F. 2006. Evaluation of 23 S rRNA PCR primers for use in phylogenetic studies of bacterial diversity. Applied and Environmental Microbiology 72(3): 22215.

Jain, S., Self, W. H., Wunderink, R. G., Fakhran, S., Balk, R., Bramley, A. M., \& Chappell, J. D. 2015. Communityacquired pneumonia requiring hospitalization among U.S. adults. New England Journal of Medicine 373(5): 415-427.

Juretschko, S., Timmermann, G., Schmid, M., Schleifer, K. H., Pommerening-Röser, A., Koops, H. P., \& Wagner, M. 1998. Combined molecular and conventional analyses of nitrifying bacterium diversity in activated sludge: Nitrosococcus mobilis and Nitrospira-like bacteria as dominant populations. Applied and Environmental Microbiology 64(8): 3042-51.

Kaur, J. \& Kaur, H. 2015. Advantages and effectiveness of bacterial culture in medical laboratories. International Journal of Advanced Research 3(8): 1028-1039

Kebbi-Beghdadi, C., Batista, C., \& Greub, G. 2011. Permissivity of fish cell lines to three Chlamydia related bacteria: Waddlia chondropbila, Estrella lausannensis and Paracblamydia acanthamoebae. FEMS Immunology \& Medical Microbiology 63(3): 339-345.

Kebbi-Beghdadi, C., Fatton, M., \& Greub, G. 2015. Permissivity of insect cells to Waddlia chondrophila, Estrella lausannensis and Parachlamydia acanthamoebae. Microbes and Infection 17(11-12): 749-754.

Kiss, A., Sain, B., \& Venetianer, P. 1977. The number of rRNA genes in Escherichia coli. FEBS Letters 79(1): 77-79.

Köksal, I., Ozlü, T., \& Bayraktar, O. 2010. Etiological agents of community-acquired pneumonia in adult patients in
Turkey; a multicentric, cross-sectional study. Tuberkuloz ve Toraks 58(2): 119-27.

Kralik, P. \& Ricchi, M. 2017. A Basic guide to real time PCR in microbial diagnostics: definitions, parameters, and everything. Frontiers in Microbiology 8: 108.

Kohli, R., Punia, R. S., Kaushik, R., Kundu, R., \& Mohan, H. 2014. Relative value of immunohistochemistry in detection of mycobacterial antigen in suspected cases of tuberculosis in tissue sections. Indian Journal of Pathology and Microbiology 57(4): 574-578.

Lamoth, F., Jaton, K., Vaudaux, B., \& Greub, G. 2011. Paracblamydia and Rhabdochlamydia: emerging agents of community-acquired respiratory infections in children. Clinical Infectious Diseases 53(5): 500-501.

Corsaro, D., Venditti, D., Le Faou, A., Guglielmetti, P., \& Valassina, M. 2001. A new chlamydia-like $16 \mathrm{~S}$ rDNA sequence from a clinical sample. Microbiology 147(3). Microbiology Society: 515-516.

Leitsch, D., Köhsler, M., Marchetti-Deschmann, M., Deutsch, A., Allmaier, G., König, L., \& Walochnik, J. 2010. Proteomic aspects of Parachlamydia acanthamoebae infection in Acanthamoeba spp. The ISME Journal 4(11): 1366-1374.

Lohr, M., Prohl, A., Ostermann, C., Liebler-Tenorio, E., Schroedl, W., Aeby, S., \& Reinhold, P. 2015. A bovine model of a respiratory Parachlamydia acanthamoebae infection. Pathogens and Disease 73(1): 1-14.

Luchsinger, V., Ruiz, M., Zunino, E., Martínez, M. A., Machado, C., Piedra, P. A., \& Gebauer, M. 2013. Community-acquired pneumonia in Chile: the clinical relevance in the detection of viruses and atypical bacteria. Thorax 68(11): 1000-1006.

Lupisan, S., Suzuki, A., Macalalad, N., Egos, R., Sombrero, L., Okamoto, M., \& de la Pena, F. 2019. Etiology and epidemiology of community-acquired pneumonia in adults requiring hospital admission: A prospective study in rural Central Philippines. International Journal of Infectious Diseases 80: 46-53.

Lutz-Wohlgroth, L., Becker, A., Brugnera, E., Huat, Z. L., Zimmermann, D., Grimm, F., \& Pospischil, A. 2006. Chlamydiales in guinea-pigs and their zoonotic potential. Journal of Veterinary Medicine Series A 53(4): 185-193.

Madico, G. E. \& Rice, P. A. 2008. 16S-ribosomal DNA to diagnose culture-negative endocarditis. Current Infectious Disease Reports 10(4): 280-286.

Maggi, R. G., Birkenheuer, A. J., Hegarty, B. C., Bradley, J. M., Levy, M. G., \& Breitschwerdt, E. B. 2014. Comparison of serological and molecular panels for diagnosis of vectorborne diseases in dogs. Parasites \& Vectors 7(1): 127.

Maneg, D., Sponsel, J., Müller, I., Lohr, B., Penders, J., Madlener, K., \& Hunfeld, K. P. 2016. Advantages and limitations of direct PCR amplification of bacterial 16S-rDNA from resected heart tissue or swabs followed by direct sequencing for diagnosing infective endocarditis: a retrospective analysis in the routine clinical setting. BioMed Research International 2016: 1-10.

Marrie, T. J., Raoult, D., La Scola, B., Birtles, R. J., \& de Carolis, E. 2001. Legionella-like and other amoebal pathogens as agents of community-acquired pneumonia. Emerging Infectious Diseases 7(6): 1026-9.

Matsuo, J., Hayashi, Y., Nakamura, S., Sato, M., Mizutani, Y., Asaka, M., \& Yamaguchi, H. 2008. Novel Parachlamydia acanthamoebae quantification method based on coculture with amoebae. Applied and Environmental Microbiology 74(20): 6397-404.

Mendoza, M., Meugnier, H., Bes, M., Etienne, J., \& Freney, J. 1998. Identification of Staphylococcus species by 16S-23S rDNA intergenic spacer PCR analysis. International Journal of Systematic Bacteriology 48(3): 1049-1055. 
Mermond, S., Berlioz-Arthaud, A., Estivals, M., Baumann, F., Levenes, H., \& Martin, P. M. 2010. Aetiology of community-acquired pneumonia in hospitalized adult patients in New Caledonia. Tropical Medicine \& International Health 15(12): 1517-1524.

Morillo, J. M., Lau, L., Sanz, M., Herrera, D., \& Silva, A. 2003. Quantitative real-time PCR based on single copy gene sequence for detection of Actinobacillus actinomycetemcomitans and Porphyromonas gingivalis. Journal of Periodontal Research 38(5): 518-524.

Shah, B. A., Singh, G., Naik, M. A., \& Dhobi, G. N. 2010. Bacteriological and clinical profile of Community acquired pneumonia in hospitalized patients. Lung India 27(2): 54.

Nascimento-Carvalho, A. C., Ruuskanen, O., \& NascimentoCarvalho, C. M. 2016. Comparison of the frequency of bacterial and viral infections among children with community-acquired pneumonia hospitalized across distinct severity categories: a prospective cross-sectional study. BMC Pediatrics 16(1): 105.

Navarro, E., Casao, M. A., \& Solera, J. 2004. Diagnosis of human brucellosis using PCR. Expert Review of Molecular Diagnostics 4(1): 115-123.

Nilsson, K., Lukinius, A., Påhlson, C., Moron, C., Hajem, N. A., Olsson, B., \& Lindquist, O. 2005. Evidence of Rickettsia spp. infection in Sweden: a clinical, ultrastructural and serological study. APMIS 113(2): 126-134.

Pilloux, L., Casson, N., Sommer, K., Klos, A., Stehle, J. C., Pusztaszeri, M., \& Greub, G. 2015. Severe pneumonia due to Parachlamydia acanthamoebae following intranasal inoculation: a mice model. Microbes and Infection 17(11-12): 755-760.

Pneumonia $\mid$ National Heart, Lung, and Blood Institute (NHLBI) 2018. Available at: https://www.nhlbi.nih.gov/healthtopics/pneumonia

Pneumonia in Children Under Five- UNICEF DATA. 2018. Available at: https://data.unicef.org/topic/child-health/ pneumonia/

Poppert, S., Essig, A., Marre, R., Wagner, M., \& Horn, M. 2002. Detection and differentiation of chlamydiae by fluorescence in situ hybridization. Applied and Environmental Microbiology 68(8): 4081-9.

Quah, J., Jiang, B., Tan, P. C., Siau, C., \& Tan, T. Y. 2018. Impact of microbial Aetiology on mortality in severe communityacquired pneumonia. BMC Infectious Diseases 18(1): 451.

Ratan, Z. A., Zaman, S. B., Mehta, V., Haidere, M. F., Runa, N. J., \& Akter, N. 2017. Application of fluorescence in situ hybridization (FISH) technique for the detection of genetic aberration in medical science. Cureus 9(6): e1325.

Regenscheit, N., Holzwarth, N., Greub, G., Aeby, S., Pospischil, A., \& Borel, N. 2012. Deer as a potential wildlife reservoir for Parachlamydia species. The Veterinary Journal 193(2): 589592.

Riffard, S., Presti, F. L., Normand, P., Forey, F., Reyrolle, M., Etienne, J., \& Vandenesch, F. 1998. Species identification of Legionella via intergenic 16S-23S ribosomal spacer PCR analysis. International Journal of Systematic Bacteriology 48(3): 723-730.

Ruhl, S., Goy, G., Casson, N., Thoma, R., Pospischil, A., Greub, G., \& Borel, N. 2008. Parachlamydia acanthamoebae infection and abortion in small ruminants. Emerging Infectious Diseases 14(12): 1966-8.

Ruhl, S., Casson, N., Kaiser, C., Thoma, R., Pospischil, A., Greub, G., \& Borel, N. 2009. Evidence for Parachlamydia in bovine abortion. Veterinary Microbiology 135(1-2): 169-174.

Sakamoto, S., Putalun, W., Vimolmangkang, S., Phoolcharoen, W., Shoyama, Y., Tanaka, H., \& Morimoto, S. 2018. Enzymelinked immunosorbent assay for the quantitative/ qualitative analysis of plant secondary metabolites. Journal of Natural Medicines 72(1): 32-42.

Sambo, F., Finotello, F., Lavezzo, E., Baruzzo, G., Masi, G., Peta, E., \& Di Camillo, B. 2018. Optimizing PCR primers targeting the bacterial $16 \mathrm{~S}$ ribosomal RNA gene. BMC Bioinformatics 19(1): 343.

Sanchez-Campillo, M., Bini, L., Comanducci, M., Raggiaschi, R., Marzocchi, B., Pallini, V., \& Ratti, G. 1999. Identification of immunoreactive proteins of Chlamydia trachomatis by Western blot analysis of a two-dimensional electrophoresis map with patient sera. Electrophoresis 20(11): 2269-2279.

Sattar, S. B. A. \& Sharma, S. 2018. Pneumonia, Bacterial. StatPearls. StatPearls Publishing.

Shibli, F., Chazan, B., Nitzan, O., Flatau, E., Edelstein, H., Blondheim, O., \& Colodner, R. 2010. Etiology of community-acquired pneumonia in hospitalized patients in northern Israel. The Israel Medical Association Journal 12(8): 477-82.

Sixt, B. S., Hiess, B., König, L., \& Horn, M. 2012. Lack of effective anti-apoptotic activities restricts growth of Parachlamydiaceae in insect cells. PLoS ONE 7(1): e29565.

Snaidr, J., Amann, R., Huber, I., Ludwig, W., \& Schleifer, K. H. 1997. Phylogenetic analysis and in situ identification of bacteria in activated sludge. Applied and Environmental Microbiology 63(7): 2884-96.

Soldati, G., Lu, Z. H., Vaughan, L., Polkinghorne, A., Zimmermann, D. R., Huder, J. B., \& Pospischil, A. 2004. Detection of Mycobacteria and Chlamydiae in granulomatous inflammation of reptiles: a retrospective study. Veterinary Pathology 41(4): 388-397.

Speicher, M. R. \& Carter, N. P. 2005. The new cytogenetics: blurring the boundaries with molecular biology. Nature Reviews Genetics 6(10): 782-792.

Spoorenberg, S. M., Bos, W. J. W., Heijligenberg, R., Voorn, P. G., Grutters, J. C., Rijkers, G. T., \& van de Garde, E. M. 2014. Microbial aetiology, outcomes, and costs of hospitalisation for community-acquired pneumonia; an observational analysis. BMC Infectious Diseases 14(1): 335.

Stubbs, S. L., Brazier, J. S., O’Neill, G. L., \& Duerden, B. I. 1999. PCR targeted to the 16S-23S rRNA gene intergenic spacer region of Clostridium difficile and construction of a library consisting of 116 different PCR ribotypes. Journal of Clinical Microbiology 37(2): 461-3.

Thanh, H. D., Park, H. K., Kim, W., \& Shin, H. S. 2013. Development of a 16S-23S rRNA intergenic spacer-based quantitative PCR assay for improved detection and enumeration of Lactococcus garvieae. FEMS Microbiology Letters 339(1): 10-16.

Valasek, M. A. \& Repa, J. J. 2005. The power of real-time PCR. Advances in Physiology Education 29(3): 151-159.

Valones, M. A. A., Guimarães, R. L., Brandão, L. A. C., Souza, P. R. E. D., Carvalho, A. D. A. T., \& Crovela, S. 2009. Principles and applications of polymerase chain reaction in medical diagnostic fields: a review. Brazilian Journal of Microbiology 40(1): 1-11.

van Gageldonk-Lafeber, A. B., Wever, P. C., Van Der Lubben, I. M., De Jager, C. P., Meijer, A., De Vries, M. C., \& van der Hoek, W. 2013. The aetiology of community-acquired pneumonia and implications for patient management. The Netherlands Journal of Medicine 71(8): 418-25.

Wheelhouse, N., Katzer, F., Wright, F., \& Longbottom, D. 2010. Novel chlamydia-like organisms as cause of bovine abortions, UK. Emerging Infectious Diseases 16(8): 1323-4.

Wheelhouse, N., Sait, M., Gidlow, J., Deuchande, R., Borel, N., Baily, J., \& Longbottom, D. 2011. Molecular detection of Chlamydia-like organisms in cattle drinking water. Veterinary Microbiology 152(1-2): 196-199. 
Wheelhouse, N., Howie, F., Gidlow, J., Greub, G., Dagleish, M., \& Longbottom, D. 2012. Involvement of Parachlamydia in bovine abortions in Scotland. The Veterinary Journal 193(2): 586-588.

Wine, Y., Horton, A. P., Ippolito, G. C., \& Georgiou, G. 2015. Serology in the 21st century: the molecular-level analysis of the serum antibody repertoire. Current Opinion in Immunology 35: 89-97.

Yamane, C., Yamazaki, T., Nakamura, S., Matsuo, J., Ishida, K., Yamazaki, S., \& Yamaguchi, H. 2015. Amoebal endosymbiont Paracblamydia acanthamoebae $\mathrm{Bn} 9$ can grow in immortal human epithelial HEp-2 cells at low temperature; an in vitro model system to study chlamydial evolution. PLOS ONE 10(2): e0116486.

Yilmaz, O. \& Demiray, E. 2007. Clinical role and importance of fluorescence in situ hybridization method in diagnosis of $H$. pylori infection and determination of clarithromycin resistance in $H$. pylori eradication therapy. World Journal of Gastroenterology 13(5): 671. 